\title{
Soldiers' perceived versus actual heat strain in a jungle environment
}

\author{
Alison Fogarty ${ }^{1 *}$, Andrew Hunt ${ }^{1}$, Catriona A Burdon² \\ From 15th International Conference on Environmental Ergonomics (ICEE XV) \\ Portsmouth, UK. 28 June - 3 July 2015
}

\section{Introduction}

Soldiers are regularly required to work in hot environments whilst wearing protective body armour (BA). However, BA is impermeable and decreases the torso surface area available for evaporative heat losses [1]. Consequently, an elevation in body core temperature was observed with early versions of BA $[2,3]$. In recent years, the size (and surface area coverage) of BA has decreased and laboratory simulations have shown that this newer BA does not increase the physiological load to the same extent as previous systems [4]. Anecdotally, however, Australian soldiers continue to report feeling an increased thermal burden when wearing BA. Therefore, we investigated the disconnect between experience and laboratory trials of the thermal impact of wearing $\mathrm{BA}$ in a warm jungle environment.

\section{Methods}

Thirty-one Australian soldiers undertook two activities (three days of patrolling and a section competition including a march, a battle run, an obstacle course and a bayonet assault course) wearing either BA and webbing (BAW) or webbing (W) only while undertaking jungle training. Although the groups were not matched due to operational constraints, there were no significant differences between the groups in anthropometric measures or aerobic capacity. Heart rate (HR) and body core temperature $\left(\mathrm{T}_{\mathrm{c}}\right)$ were measured using a physiological monitoring system. Perceived heat illness symptoms were measured using the Environmental Symptoms Questionnaire (ESQ; 22 statements) [5]. Environmental conditions were measured using a wet bulb globe thermometer (WBGT).

\footnotetext{
* Correspondence: Alison.Fogarty@dsto.defence.gov.au

'Land Division, Defence Science and Technology Organisation, Melbourne, Australia

Full list of author information is available at the end of the article
}

\section{Results}

The WBGT was $24-25{ }^{\circ} \mathrm{C}$ and $20{ }^{\circ} \mathrm{C}$ for the section patrol days and section competition respectively. The physiological measures (HR and $\mathrm{T}_{\mathrm{c}}$ ) were not significantly different between the BAW and W groups during both activities. The summed ESQ rating was not different between groups during the patrol days, however six individual statements were higher with the BAW group. In contrast, after the section competition both the sum of ratings and 7 statements were significantly higher in the BAW group.

\section{Discussion}

Similar to laboratory simulations, BA (with reduced surface area) did not impose a greater thermal strain on soldiers in a warm jungle environment. Despite this finding, the ESQ indicates that the soldiers wearing BA perceived that they were under greater thermal strain.

\section{Conclusion}

The findings of the present study suggest that, if operational needs require soldiers to wear BA in a jungle environment, there is not an increased risk of personnel becoming a heat casualty. However, soldiers perceive themselves to be more uncomfortable and thus may be less able to concentrate on the mission.

\footnotetext{
Authors' details

${ }^{1}$ Land Division, Defence Science and Technology Organisation, Melbourne, Australia. ${ }^{2}$ Centre for Human and Applied Physiology, School of Medicine, University of Wollongong, Wollongong, Australia.

Published: 14 September 2015

\section{References}

1. Pascoe DD, Shanley LA, Smith EW: Clothing and exercise. I: Biophysics of heat transfer between the individual, clothing and environment. Sports Med 1994, 18(1):38-54.
} creativecommons.org/licenses/by/4.0), which permits unrestricted use, distribution, and reproduction in any medium, provided the original work is properly cited. The Creative Commons Public Domain Dedication waiver (http://creativecommons.org/publicdomain/ zero/1.0/) applies to the data made available in this article, unless otherwise stated. 
2. Goldman RF: Physiological costs of body armour. Military Medicine 1969, 134(3):204-10.

3. Haisman MF, Goldman RF: Physiological Evaluations of Armoured Vests in Hot-Wet and Hot-Dry Climates. Ergonomics 1974, 17(1):1-12.

4. van den Heuvel AMJ, et al: The effect of a four-tier body armour system on body-heat retention and physiological strain. UOW-CHAP-HPL-Report040 Wollongong, University of Wollongong; 2010.

5. Sampson JB, Kobrick JL, Johnson RF: Measurement of subjective reactions to extreme environments: The environmental symptoms questionnaire. Military Psychology 1994, 6(4):215-233.

doi:10.1186/2046-7648-4-S1-A21

Cite this article as: Fogarty et al:: Soldiers' perceived versus actual heat strain in a jungle environment. Extreme Physiology \& Medicine 2015

4(Suppl 1):A21.

Submit your next manuscript to BioMed Central and take full advantage of:

- Convenient online submission

- Thorough peer review

- No space constraints or color figure charges

- Immediate publication on acceptance

- Inclusion in PubMed, CAS, Scopus and Google Scholar

- Research which is freely available for redistribution

Submit your manuscript at www.biomedcentral.com/submit 